\title{
Mefenamic acid-induced neutropenia and renal failure in elderly females with hypothyroidism
}

\author{
S.I. Handa and S. Freestone
}

\author{
Department of Haematology and ${ }^{1}$ Department of Clinical Pharmacology, Royal Infirmary, 1 Lauriston \\ Place, Edinburgh EH3 $9 Y W, U K$.
}

\begin{abstract}
Summary: We report mefenamic acid-induced non-oliguric renal failure and severe neutropenia occurring simultaneously in two elderly females. The neutropenia was due to maturation arrest of the myeloid series in one patient. Both patients were also hypothyroid, but it is not clear whether this was a predisposing factor to the development of these adverse reactions. However, it would seem prudent not to use mefenamic acid in hypothyroid patients until the hypothyroidism has been corrected.
\end{abstract}

\section{Introduction}

Mefenamic acid, a phenylanthranilic acid derivative, has been available clinically for more than 20 years and is widely used as a non-steroidal anti-inflammatory drug (NSAID). In common with other NSAIDs nephrotoxicity may occur, particularly in the elderly. ${ }^{1,2}$ Leucopenia may also rarely occur. $^{3}$ We report two cases of elderly patients with previously undiagnosed hypothyroidism who developed renal failure and severe neutropenia simultaneously during mefenamic acid therapy.

\section{Case reports}

Case 1

An 83 year old female was admitted with fractured pubic rami and was commenced on mefenamic acid $500 \mathrm{mg}$ four times a day for pain relief. Her other drug treatment was diazepam and triazolam. Twenty five days after starting mefenamic acid she became drowsy and confused but there were no focal neurological signs. Plasma biochemistry showed a raised urea of $28.5 \mathrm{mmol} / 1$, creatinine of $229 \mu \mathrm{mol} / \mathrm{l}$, potassium of $5.2 \mathrm{mmol} / 1$ and a low total bicarbonate of $16 \mathrm{mmol} / \mathrm{l}$. The haematology showed haemoglobin $(\mathrm{Hb})$ of $9.3 \mathrm{~g} / \mathrm{dl}$ (normal range $11.5-16.5 \mathrm{~g} / \mathrm{dl}$ ), a low total white cell count (WCC) of $2.1 \times 10^{9} / 1$ (normal range 4.0 $\left.11.0 \times 10^{9} / 1\right)$ with only $17 \%$ neutrophils and a normal platelet count. Two days previously the results had been relatively normal ( $\mathrm{Hb} 10.4 \mathrm{~g} / \mathrm{dl}$, WCC $4.1 \times 10^{9} / 1$ with $77 \%$ neutrophils). Urin-

Correspondence: S.I. Handa, B. Med. Sci., M.R.C.P. Accepted: 7 February 1990 alysis showed specific gravity $1.010, \mathrm{pH} 6.0$ and protein + .

A diagnosis of non-oliguric renal failure and neutropenia secondary to mefenamic acid was suspected. All drugs were discontinued and she was given intravenous fluids with improvement in her general condition. Within 3 days her plasma biochemistry had improved, the urea falling to $9.9 \mathrm{mmol} / \mathrm{l}$. However, her blood counts continued to deteriorate $\left(\mathrm{Hb} 8.7 \mathrm{~g} / \mathrm{dl}\right.$ and WCC $1.2 \times 10^{9} / 1$ with only $2 \%$ neutrophils). None the less she had remained reasonably well and apyrexial. Her only symptoms were of weakness and tiredness. On direct questioning she admitted to puffiness of her face and dryness of her skin. There was no history of cold intolerance, however. On examination there were no signs of infection. She had a dry skin and myxoedematous facies.

Plasma biochemistry showed further improvement, the urea falling to $7.9 \mathrm{mmol} / \mathrm{l}$ and creatinine becoming normal at $111 \mu \mathrm{mol} / \mathrm{l}$. Serum thyroxine was $28 \mathrm{nmol} / 1$ (normal range for over 65 years, $55-140 \mathrm{nmol} / \mathrm{l})$ with a thyroid stimulating hormone of $10.1 \mathrm{mU} / 1$ (normal $<5.7 \mathrm{mU} / \mathrm{l})$. Bone marrow biopsy showed maturation arrest of the myeloid series with little development beyond the myelocyte stage. Serum autoantibodies including thyroid cytoplasm, thyroglobulin and anti-nuclear factor (ANF) were negative.

She was commenced on thyroxine $25 \mu \mathrm{g}$ daily, folic acid $5 \mathrm{mg}$ three times a day and vitamin B12 $1 \mathrm{mg}$ intramuscularly on 4 consecutive days. Her blood counts recovered rapidly and 12 days after stopping mefenamic acid her absolute neutrophil count had returned to normal at $2.46 \times 10^{9} / 1$ (normal range 2.0-7.5 $\times 10^{9} / 1$ ) and haemoglobin had risen to $10.0 \mathrm{~g} / \mathrm{dl}$. She remained apyrexial throughout her admission and was discharged. 
Case 2

A 72 year old female was admitted with a history of recurrent falls. She had been taking mefenamic acid $500 \mathrm{mg}$ four times a day since sustaining fractures of the left pubic rami 4 months previously. She had noticed cold intolerance and weight gain for several months and had had diarrhoea over the previous few days.

On examination she was frankly myxoedematous with anaemia, erythema ab igne, temperature $34.5^{\circ} \mathrm{C}$ and pulse rate of 45 per min. Investigations showed $\mathrm{Hb} 10.4 \mathrm{~g} / \mathrm{dl}$, WCC $1.8 \times 10^{9} / 1(22 \%$ neutrophils $)$ and a normal platelet count. Plasma urea was elevated at $27.9 \mathrm{mmol} / \mathrm{l}$ with a creatinine of $503 \mu \mathrm{mol} / \mathrm{l}$. Abdominal ultrasound scan showed normal sized, non-obstructed kidneys. Serum total thyroxine was low at $<20 \mathrm{nmol} / 1$ and TSH markedly elevated at $49 \mathrm{mU} / \mathrm{l}$. Antibodies to thyroid cytoplasm and microsomes were present but antinuclear factor was negative. Urine microscopy showed no casts or red cells.

Mefenamic acid was stopped and she was treated with intravenous fluids. Two days later the WCC had fallen to $1.0 \times 10^{9} / 1(2 \%$ neutrophils). Thyroxine was commenced. Six days after stopping mefenamic acid WCC had increased to $7.1 \times 10^{9} / 1$ ( $81 \%$ neutrophils). Renal function improved over 2 weeks (urea $8 \mathrm{mmol} / \mathrm{l}$, creatinine $190 \mu \mathrm{mol} / \mathrm{l}$ ). Haemoglobin fell steadily over 3 weeks to a nadir of $6.6 \mathrm{~g} / \mathrm{dl}$ and she required transfusion of 4 units of red cell concentrate. There was no evidence of haemolysis and faeces were repeatedly negative for occult blood. Following transfusion her $\mathrm{Hb}$ was maintained. She was discharged on thyroxine $100 \mu \mathrm{g}$ daily and at follow up serum thyroxine and TSH were normal. Two months later renal function was almost normal (urea $5.6 \mathrm{mmol} / \mathrm{l}$ creatinine $151 \mu \mathrm{mol} / \mathrm{l})$.

\section{Discussion}

Although Prescott ${ }^{4}$ in his review of the drug in 1968 reported temporary leucopenia, we could only find one report of 5 elderly cases in the English literature ${ }^{3}$ and only one other report world-wide. ${ }^{5}$ Both our patients were leucopenic, in particular severely neutropenic. In addition they were anaemic, whereas all the 5 cases reported by Burns and Young ${ }^{3}$ had isolated leucopenia. The anaemia in our patients can probably be explained by the hypothyroidism and the renal failure. However, leucopenia is not a feature of hypothyroidism; indeed, this tends to occur in hyperthyroidism. ${ }^{6}$ Mefenamic acid is well recognized to cause a Coombs' positive haemolytic anaemia ${ }^{7}$ but there was no evidence of haemolysis in our patients.
Burns and Young ${ }^{3}$ speculated that the cause of the leucopenia was likely to be leucocyte agglutinins although they provided no evidence for this. However, bone marrow biopsy in one of our patients showed the cause of the neutropenia to be maturation arrest of the myeloid series. We suggest that the latter is the much more likely pathogenetic mechanism for the neutropenia.

Non-oliguric renal failure is a well-recognized complication of mefenamic acid therapy, particularly in the elderly. ${ }^{1,2}$ It is commonly preceded by the development of diarrhoea, as in one of our patients. Other risk factors, including pre-existing renal disease, concurrent diuretic therapy or other causes of dehydration, were not present in our cases. Renal function usually returns to pretreatment levels on stopping the drug and correcting any dehydration. A variety of renal pathologies have been implicated but interstitial nephritis is the most common lesion identified on biopsy. ${ }^{8}$

The development of neutropenia and renal failure almost simultaneously with mefenamic acid has not been previously described. Both of our patients were elderly and both received higher doses $(2 \mathrm{~g} /$ day $)$ than the $1.5 \mathrm{~g} /$ day recommended in the data sheet. ${ }^{9}$ It is not clear whether our patients' hypothyroidism was a predisposing factor to the development of these adverse reactions. It should be noted that our patients were truly hypothyroid as evidenced by their clinical state and elevated TSH concentration. Although mefenamic acid has been shown to lower total plasma thyroxine levels by a displacement effect on plasma protein binding, this is associated with a suppressed TSH concentration. ${ }^{10}$

Mefenamic acid undergoes oxidation to $3^{\prime}$ hydroxymethyl and 3' carboxyl derivatives. Most of the former and $50 \%$ of the latter are conjugated with glucuronide. ${ }^{11}$ Although reduced drug metabolism commonly occurs in hypothyroidism, without specific study it is not possible to predict the effect of altered thyroid function on the metabolism of any individual drug. ${ }^{12}$ There is no published information on the effect of the hypothyroid state on the metabolism of mefenamic acid (Parke-Davis, personal communication).

Approximately $50 \%$ of an oral dose of mefenamic acid undergoes urinary excretion mainly as its metabolites and only $6 \%$ as unchanged drug. " Accumulation therefore occurs in patients with renal impairment. Thus, if renal dysfunction develops with mefenamic acid therapy, it may become self-perpetuating.

In the light of these cases it would be prudent not to use mefenamic acid in hypothyroid patients until the hypothyroidism has been corrected. It has been suggested that regular blood counts are mandatory even in asymptomatic elderly patients taking 
mefenamic acid in order to detect leucopenia early. ${ }^{3}$ However, this may not help as the leucocyte count fell very rapidly (over 2 days) in one of our patients. In view of the susceptibility of elderly patients to severe adverse reactions with mefenamic acid, it may be questioned whether this drug should ever be used in this age group.

\section{References}

1. Robertson, C.E., Ford, M.J., Van Someren, V., Dlugolecka, M. \& Prescott, L.F. Mefenamic acid nephropathy. Lancet 1980, ii: $232-233$.

2. Taha, A., Lenton, R.J., Murdoch, P.S. \& Peden, N.R. Non-oliguric renal failure during treatment with mefenamic acid in elderly patients: a continuing problem. Br Med J (Clin Res) 1985, 291: 661-662.

3. Burns, A.\& Young, R.E. Mefenamic acid induced leucopenia in the elderly (letter). Lancet 1984, ii: 46.

4. Precott, L.F. Mefenamic acid. Prescribers' J 1968, 8: $109-112$.

5. Euler, H.H., Kleine, L. \& Herrlinger, J.D. Neutropenia induced by mephenaminic acid (letter). Dtsch Med Wochenschr 1980, 105: 1192-1193.

6. Irvine, W.J., Wu, F.C.W., Urbaniak, S.T. \& Toolis, F. Peripheral blood leucocytes in thyrotoxicosis (Graves' disease) as studied by conventional light microscopy. Clin Exp Immunol 1977, 27: 216-221.

\section{Acknowledgements}

We are very grateful to Dr C.A. Ludlam for permitting us to report a patient under his care and for constructive criticism of the manuscript.

7. Petz, L.D. Drug-induced immune haemolytic anaemia. Clin Haematol 1980, 9: 455-482.

8. Jenkins, D.A.S., Harrison, D.J., MacDonald, M.K. \& Winney, R.J. Mefenamic acid nephropathy: an interstitial and mesangial lesion. Nephrol Dial Transplant 1988; 2: 217-220.

9. Parke-Davis Research Laboratories. In: $A B P I$ data sheet compendium. Datapharm Publications, London, 1989-90, pp. $1208-1211$.

10. Koizumi, Y., Sato, A., Yamada, T. \& Inada, M. Effect of mefenamic acid on plasma protein-thyroid hormone interaction, monodeiodination of thyroxine, urinary excretion of tri-iodothyronine and thyrotrophin regulation. Clin Exp Pharmacol Physiol 1984, 11: 291-299.

11. Gilman, A.G., Goodman, L.S. \& Gilman, A. (eds). The Pharmacological Basis of Therapeutics. MacMillan, New York, 1980, pp. 708.

12. Shenfield, G.M. Influence of thyroid dysfunction on drug pharmacokinetics. Clin Pharmacokinet 1981, 6: 275-297. 